\title{
Penerapan Metode Rootcause Analysis (RCA) dalam Pengembangan Kawasan Wisata Cagar Budaya Kampung Kemasan, Gresik
}

\author{
Dian Rahmawati ${ }^{1}$ \\ Rimadewi Suprihardjo \\ Eko Budi Santoso ${ }^{3}$ \\ Rulli P. Setiawan ${ }^{4}$ \\ Karina Pradinie ${ }^{5}$ \\ Mochamad Yusuf ${ }^{6}$
}

${ }^{1}$ Urban and Regional Planning Department, Institut Teknologi Sepuluh Nopember, Indonesia

Email : d_rahmawati@urplan.its.ac.id

\begin{abstract}
In a planning process, appropriate methods in order to understand the problems is needed so that proper planning products targeted to answer the challenge on a case study. Root cause analysis (RCA) is a qualitative analysis method that serves to attract understanding the root causes of problem which is need to be considered in the formulation stage of product planning. The tourist area of cultural heritage Kampung Kemasan has potential as a tourist development area but his condition is not developed well. Kampung Kemasan chosen as a case study to be aligned with the functions deemed appropriate method of RCA as a tools to understand the root cause of an event. The use of RCA is expected to become effective tools for basic guidelines for the formulation of the product development of the region based on a comprehensive understanding of an event.
\end{abstract}

Keyword : Rootcause analysis, heritage tourism, Kampung Kemasan 


\section{PENDAHULUAN}

Memahami proses bagaimana sebuah peristiwa terjadi adalah kunci untuk merumuskan sebuah rekomendasi yang efektif ketika kesalahan atau error terjadi. Rootcause analysis (RCA) adalah sebuah tools yang didesain untuk memahami akar penyebab permasalahan sebuah peristiwa didasarkan pada kausalitas dalam sebuah proses. RCA berfungsi untuk mengidentifikasi dan mengkategorikan permasalahan yang menjadi penyebab terjadinya sesuatu pada sebuah peristiwa. Dalam proses identifikasi dan kategorisasi, informasi yang dijelaskan tidak hanya "apa" dan "bagaimana" namun juga mengakomodir " kenapa" sebuah peristiwa itu terjadi [1].

Artikel ini berusaha

mendeskripsikan hasil evaluasi keefektifan penerapan RCA dalam memahami kondisi sebuah wilayah terkait permasalahan sehingga pertimbangan pemahaman dapat digunanan sebagai dasar penyusunan perencanaan dan pengembangan sebuah kawasan. Dalam merumuskan pertimbangan sebagai pedoman perencanaan, terdapat beberapa teknik analisis yang sering digunakan diantaranya SWOT, AHP, Delphi, atau content analysis. Masing - masing analisis ini memiliki karakteristik yang berbeda baik dari fungsi, bentukan output, maupun tahapan dalam penggunaannya. Persamaan antar teknik-teknik analisis tersebut adalah tujuannya yang digunakan sebagai pedoman perumusan produk rencana berdasarkan deskripsi pemahaman sebuah peristiwa. RCA sebagai metoda pendekatan dan analisa memiliki fungsi yang mampu memahami sebuah peristiwa secara komprehensif. Pemahaman secara komprehensif ini kemudian diharapkan dapat pula menjadi acuan pedoman perumusan strategi yang tepat dalam penerapan konsep perencanaan dalam studi kasus.

Kampung Kemasan dipilih sebagai studi kasus dilatarbelakangi oleh potensi kampung yang merupakan kawasan cagar budaya dan memiliki potensi wisata budaya di Gresik. Kampung ini merupakan salah satu bukti peninggalan sejarah yang ditetapkan sebagai kawasan cagar budaya. Kawasan cagar budaya merupakan kawasan yang urgen strategis dalam perencanaan perkotaan dimana kelestariannya perlu diperhatikan [2].

Pemanfaatan kampung sebagai kawasan wisata terlihat dari adanya beberapa pengunjung dari skala domestik hingga internasional. Para pengunjung dapat melihat dan mengadakan studi mengenai peninggalan bangunan rumah tinggal yang memilki arsitektur Cina, Arab dan Eropa [3]. Potensi pariwisata dalam Kampung Kemasan juga diperkuat dengan adanya Komunitas Masyarakat Pecinta Sejarah dan Budaya Gresik (MATASEGER) yang berdiri pada tahun 2009. Komunitas ini berperan dalam pengenalan budaya kampung secara historis dengan menjadi guide bagi wisatawan. Salah satu program dari Komunitas MATASEGER adalah Gresik Djaloe (Djaman Doeloe), yaitu program jalan-jalan wisata sejarah dan budaya dengan agenda mengunjungi Kampung Kemasan. Program ini dinobatkan sebagai Juara Daya Tarik Wisata Favorit melalui ajang Anugerah Wisata Jatim 2011 dan selanjutnya Komunitas MATASEGER berencana membawa program ini ke ranah internasional.

Keberadaan potensi yang menjadi penunjang daya tarik kawasan wisata cagar budaya kampung kemsasan ini berbanding terbalik dengan data Dinas Kebudayaan dan Pariwisata Jawa Timur yang menyatakan bahwa terjadi penurunan jumlah wisatawan per bulan setiap tahunnya. Disisi lain terdapat beberapa permasalahan dimana pelestarian kawasan cagar budaya di Kota Gresik saat ini masih dalam taraf raperda pada tahun 2011, sehingga banyak bangunan atau situs cagar budaya yang belum ditetapkan sebagai kawasan cagar budaya, akibatnya secara 
drastis terjadi penurunan bangunan dari 500 bangunan yang pernah didata pada tahun 1990-an menjadi hanya 125 bangunan saja [4].

Latar belakang permasalahan tidak berkembangnya kawasan wisata cagar budaya Kampung Kemasan dibandingkan dengan potensi wisata yang dinilai potensial guna mendukung pengembangan menjadi latar belakang mengapa studi kasus dipilih. Keefektifan metode RCA dalam mengupas dan memahami secara mendalam faktor - faktor apa yang menyebabkan lambatnya perkembangan wisata Kampung Kemasan merupakan latar belakang yang menjadi dasar penulisan artikel ini. Dengan diketahuinya tingkat keefektifan metode RCA maka pertimbangan penggunaan metode ini dalam proses perencanaan dapat diperhitungkan.

\section{METODE}

RCA secara umum merupakan metoda analisa penelitian kualitatif yang dilakukan dengan membangun konstruksi pemaknaan empirik, logik, dan etik berdasarkan argumentasi dan pemaknaan atas fenomena yang diteliti. Penggambaran argumentasi dan pemaknaan dilakukan dengan penggambaran deskripsi deskripsi guna membentuk pemahaman yang komprehensif [5]. RCA dilakukan dengan beberapa tahapan antara lain : inventarisasi data, penyusunan diagram sebab - akibat, analisa penyebab akar permasalahan, dan penyusunan rekomendasi. Secara proses, tujuan utama dari RCA adalah mengidentifikasi dan memahami "apa, bagaimana, dan mengapa" pada sebuah peristiwa untuk kemudian dirumuskan strategi yang tepat dalam penanganan permsalahan terkait "error" yang ditemukan dalam proses analisa.

Data yang digunakan dalam penerapan metode analisa RCA dalam pengembangan wisata budaya Kampung Kemasan berupa data sekunder dan primer. Data sekunder berupa kajian literature terutama dari penelitian terdahulu, berita aktual dari berbagai sumber media cetak maupun online, serta dokumen milik masyarakat maupun pemerintah terkait kawasan wisata Kampung Kemasan. Data primer didapatkan dari (i) informasi hasil observasi langsung dan wawancara, (ii) informasi berupa pendapat, opini, presepsi dan pemahaman mengenai suasana dikawasan, perilaku masyarakat kota pada umumnya dan masyarakat sekitar kawasan pada khususnya, pikiran-pikiran tentang kehidupan serta pendapat tentang kondisi fisik kawasan, dan (iii) pengamatan langsung terhadap seluruh aktifitas yang terjadi di kawasan penelitian penelitian. Ragam narasumber meliputi instansi terkait yaitu Disbudparpora Kab. Gresik, Duta Pariwisata Kab. Gresik 2015/2016, masyarakat pemilik bangunan di kawasan kampung kemasan dan Ketua Komunitas Masyarakat Pecinta Cagar Budaya Gresik.

\section{HASIL DAN PEMBAHASAN}

Evaluasi terhadap metode yang lain guna melihat efektivitas metoda RCA

Dalam penelitian maupun proses perencanaan terdapat beberapa metode kualitatif yang dapat digunakan sebagai dasar perumusan strategi pengembangan sebuah wilayah atau kawasan (dengan karakteristik tertentu) diantaranya adalah SWOT, AHP, DELPHI, Content Analysis. Penggunaan metode diatas secara umum berfungsi sebagai pedoman dalam perumusan pertimbangan strategi dalam sebuah perencanaan. Secara detail masing - masing fungsi metode analisa adalah :

Tabel 1. Komparasi metode dalam penentuan pertimbangan dasar pada proses perencanaan

\begin{tabular}{|c|c|c|}
\hline FUNGSI & OUTPUT & KETERANGAN \\
\hline \multicolumn{3}{|c|}{ SWOT [6] (Gretzky,2010) } \\
\hline $\begin{array}{l}\text { Memahami } \\
\text { kondisi } \\
\text { permasalahan } \\
\text { guna } \\
\text { merumuskan } \\
\text { strategi } \\
\text { penanganan }\end{array}$ & $\begin{array}{l}\text { Strategi } \\
\text { penanganan } \\
\text { sebuah } \\
\text { permasalahan } \\
\text { berdasarkan } \\
\text { pembagian } \\
\text { aspek } \\
\text { kekuatan, }\end{array}$ & $\begin{array}{l}\text { Dilakukan dengan } \\
\text { tahapan : } \\
\text { - Penentuan tujuan } \\
\text { yang spesifik; } \\
\text { - Identifikasi faktor } \\
\text { internal; } \\
\text { - Identifikasi faktor }\end{array}$ \\
\hline
\end{tabular}




\begin{tabular}{|c|c|c|}
\hline FUNGSI & OUTPUT & KETERANGAN \\
\hline & $\begin{array}{l}\text { kelemahan, } \\
\text { kesempatan, } \\
\text { dan ancaman }\end{array}$ & $\begin{array}{l}\text { eksternal; } \\
\text { - Internal-External } \\
\text { Analysis melalui } \\
\text { SWOT Matrix } \\
\text { atau IE Matrix }\end{array}$ \\
\hline \multicolumn{3}{|c|}{ Content Analysis [7]. (Shannon, 2005) } \\
\hline $\begin{array}{l}\text { Memahami } \\
\text { sebuah } \\
\text { kondisi/ } \\
\text { peristiwa } \\
\text { berdasarkan } \\
\text { hasil deteksi, } \\
\text { rekam, dan } \\
\text { analisa } \\
\text { keberadaan } \\
\text { kalimat atau } \\
\text { konsep yang } \\
\text { spesifik } \\
\text { dalam sebuah } \\
\text { sampel text }\end{array}$ & $\begin{array}{l}\text { pemahaman } \\
\text { kontekstual } \\
\text { mengenai } \\
\text { peristiwa } \\
\text { berdasarkan } \\
\text { dari proses } \\
\text { analisis. }\end{array}$ & $\begin{array}{l}\text { Dilakukan dengan : } \\
\text { - Perumusan } \\
\text { permasalahan } \\
\text { - Menentukan } \\
\text { sample } \\
\text { - Coding informasi } \\
\text { dari sample } \\
\text { Interpretasi }\end{array}$ \\
\hline \multicolumn{3}{|c|}{ AHP [8]. (Saaty, 2008) } \\
\hline
\end{tabular}

\section{Penggunaan metoda RCA dalam studi} kasus

\begin{tabular}{|c|c|c|}
\hline $\begin{array}{l}\text { Alat evaluasi } \\
\text { dan } \\
\text { representasi } \\
\text { solusi } \\
\text { berdasarkan } \\
\text { pemilihan } \\
\text { prioritas } \\
\text { melalui } \\
\text { pengujian } \\
\text { kualitas } \\
\text { keputusan }\end{array}$ & $\begin{array}{l}\text { Pemilihan } \\
\text { prioritas } \\
\text { keputusan } \\
\text { berdasarkan } \\
\text { pertimbangan } \\
\text { expert }\end{array}$ & $\begin{array}{l}\text { Dilakukan dengan } \\
\text { tahapan } \\
\text { - Menentukan } \\
\text { tujuan, } \\
\text { kriteria/faktor, } \\
\text { alternatif pilihan } \\
\text { keputusan } \\
\text { - Membuat pohon } \\
\text { hirarki (hierarchy } \\
\text { tree) } \\
\text { - Membentuk } \\
\text { matriks pairwise } \\
\text { comparison } \\
\text { - Membuat } \\
\text { peringkat } \\
\text { prioritas } \\
\text { kriteria/faktor } \\
\text { - Membuat } \\
\text { peringkat } \\
\text { prioritas alternatif } \\
\text { dari matriks } \\
\text { pairwise } \\
\text { comparasion } \\
\text { - Uji konsistensi } \\
\text { hasil peringkat } \\
\text { prioritas }\end{array}$ \\
\hline \multicolumn{3}{|c|}{ DELPHI [9]. (Chien Hzu, 2007) } \\
\hline
\end{tabular}

\begin{tabular}{|l|l|l|}
\hline \multicolumn{1}{|c|}{ FUNGSI } & \multicolumn{1}{|c|}{ OUTPUT } & \multicolumn{1}{|c|}{ KETERANGAN } \\
\hline Menentukan & Pemilihan & Dilakukan dengan \\
keputusan & prioritas & tahapan \\
yang diambil & keputusan & • Formulasi isu \\
dari gambaran & berdasarkan & $\bullet$ Penentuan expert \\
kondisi & pertimbangan & • Perumusan \\
permasalahan, & expert & kuisoner \\
studi kasus & & - Analisis \\
atau gejala & & $\bullet$ iterasi \\
gejala tertentu & & \\
mengenai & & \\
sesuatau & & \\
\hline
\end{tabular}

Dari karakteristik masing - masing metoda analisa yang digunakan dalam penentuan keputusan dalam perencanaan terdapat beberapa prinsip yang menjadi ciri dari metoda diantaranya : (i) identifikasi pemahaman terhadap studi kasus, (ii) hasil analisa merupakan produk pertimbangan dalam perumusan strategi penanganan masalah, dan (iii) melibatkan expert sebagai narasumber. Prinsip ini yang kemudian digunakan sebagai tools evaluasi apakah metoda RCA merupakan metoda yang efektif digunakan dalam memahami sebuah peristiwa sehingga dapat digunakan sebagai pertimbangan proses perencanaan.

Tahapan pertama dalam perumusan RCA adalah inventarisasi data dengan identifikasi variabel yang ditetapkan sebagai amatan. Variabel yang diamati terkait indikator pengembangan wisata Cagar Budaya Kampung Kemasan, Gresik adalah :

Tabel 2 indikator dan variabel yang berpengaruh terhadap pengembangan wisata

\begin{tabular}{|l|l|}
\hline INDIKATOR & \multicolumn{1}{|c|}{ VARIABEL } \\
\hline Daya tarik & $\begin{array}{l}\text { Pemanfaatan bangunan cagar } \\
\text { budaya sebagai atraksi }\end{array}$ \\
\cline { 2 - 3 } & $\begin{array}{l}\text { Pemanfaatan kebudayaan } \\
\text { setempat sebagai atraksi }\end{array}$ \\
\cline { 2 - 2 } dan & $\begin{array}{l}\text { Keberadaan obyek wisata lain di } \\
\text { sekitar kawasan wisata }\end{array}$ \\
\hline $\begin{array}{l}\text { Sarana } \\
\text { prasarana }\end{array}$ & $\begin{array}{l}\text { Akomodasi dari masyarakat } \\
\text { lokal }\end{array}$ \\
\hline
\end{tabular}




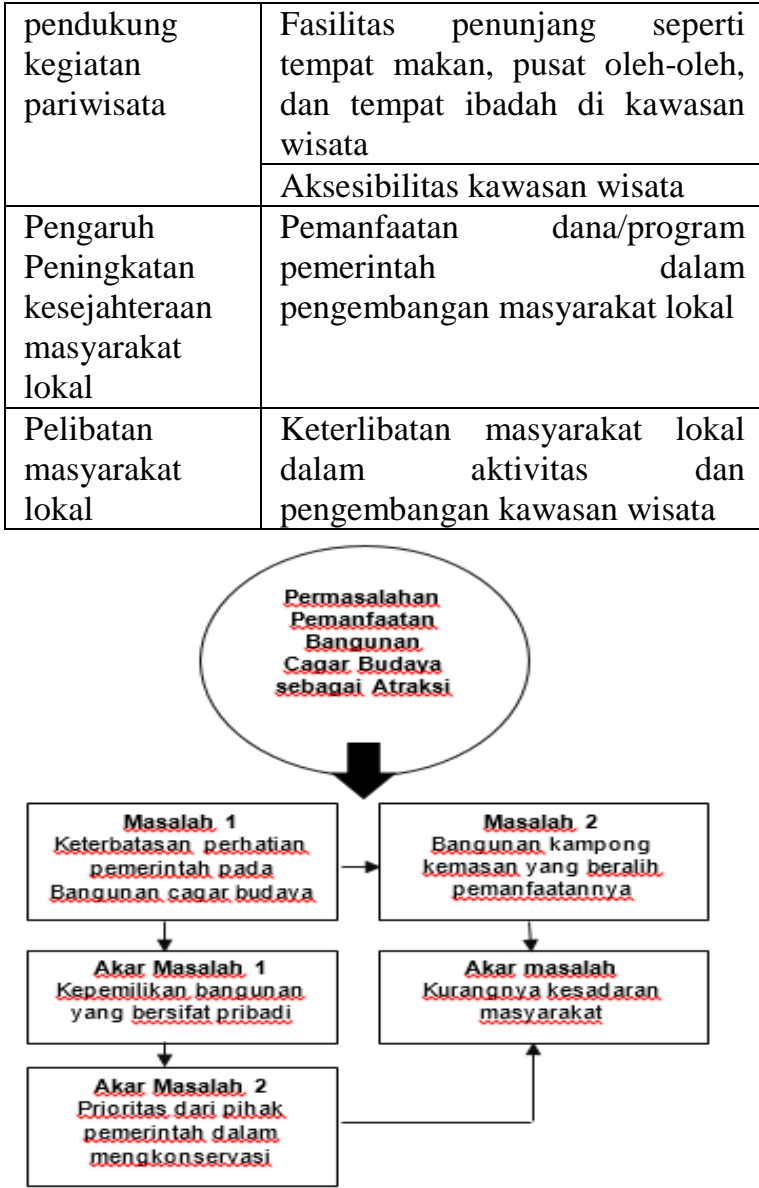

Diagram 1. Akar permasalahan terkait Daya Tarik 1

Dari poin - poin indikator dan variabel digambarkan kondisi pada wilayah studi. hasil inventarisir data terkait gambaran kondisi variabel yang ditentukan guna pengaruhnya terhadap pengembangan kawasan adalah [10] :

\section{- Daya Tarik}

\section{Pemanfaatan Bangunan Cagar Budaya sebagai Atraksi}

Pemanfaatan bangunan cagar budaya sebagai atraksi utama di Kampung Kemasan sangat penting namun kondisi aktual kini terdapat beberapa bangunan yang mengalami alif fungsi pemanfaatan disamping bangunan yang sudah dilindungi oleh pemerintah (dikonservasi). Kondisi ini disebabkan karena kepemilikan bangunan yang masih bersifat pribadi sehingga pemerintah tidak memiliki kuasa penuh terhadap bangunan cagar budaya. Dampak yang terlihat kini adalah terhadap penentuan prioritas oleh pemerintah terkait konservasi bangunan yang cenderung terhambat. Kondisi ini juga dipengaruhi oleh tingkat kesadaran masyarakat yang cenderung minim dalam upaya pelestarian kawasan.

\section{Pemanfaatan Kebudayaan Setempat}

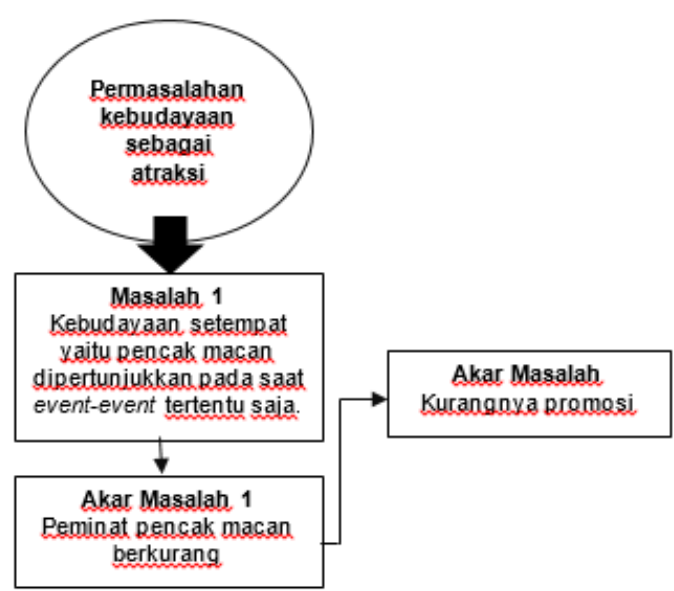

Diagram 2. Akar permasalahan terkait Daya Tarik 2

\section{sebagai Atraksi}

Kebudayaan setempat merupakan potensi yang dapat dijadikan sebagai salah satu atraksi wisata utama. Permasalahan terkait kebudayaan adalah sifatnya yang tidak terorganisir dimana pertunjukan budaya hanya disajikan secara eventual dan tidak terjadwal. Produk budaya yang popular di kampung kemasan seperti misalnya pencak macan kini cenderung berkurang dikarenakan minimnya promosi. 
Keberadaan Obyek Wisata Lain di Sekitar Kawasan Wisata

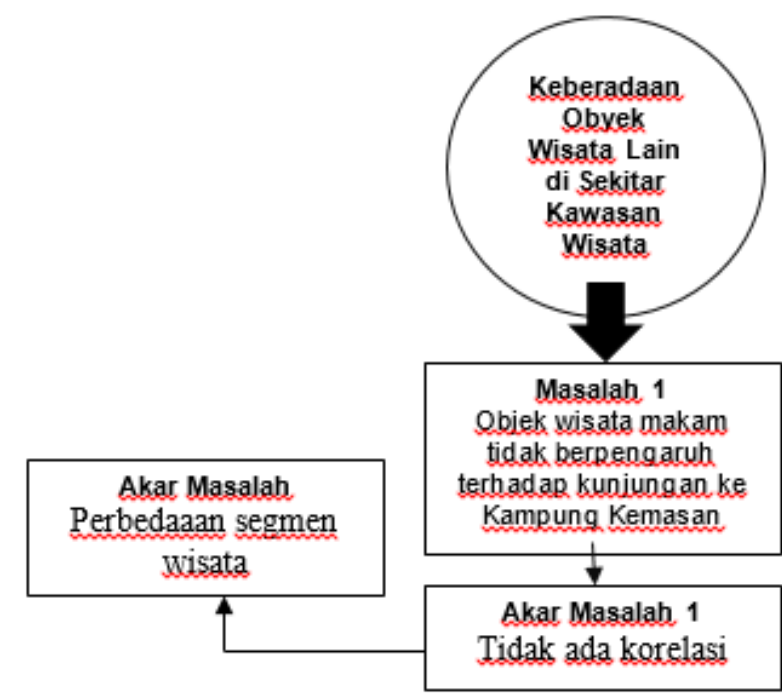

Diagram 3. Akar permasalahan terkait Daya Tarik 3

Terdapat beberapa objek wisata disekitar Kampung Kemasan yang dapat dijadikan tambahan daya Tarik wisata. Namun kondisi saat ini, objek wisata lain ini tidak begitu memiliki pengaruh terhdap kondisi wisata kampung kemasan. Tidak adanya pengaruh antar objek wisata ini dikarenakan tidak adanya korelasi antara jenis wisata, segmen peminat dan kemasan produk wisata yang memang tidak dimanajemen untuk saling terkait.

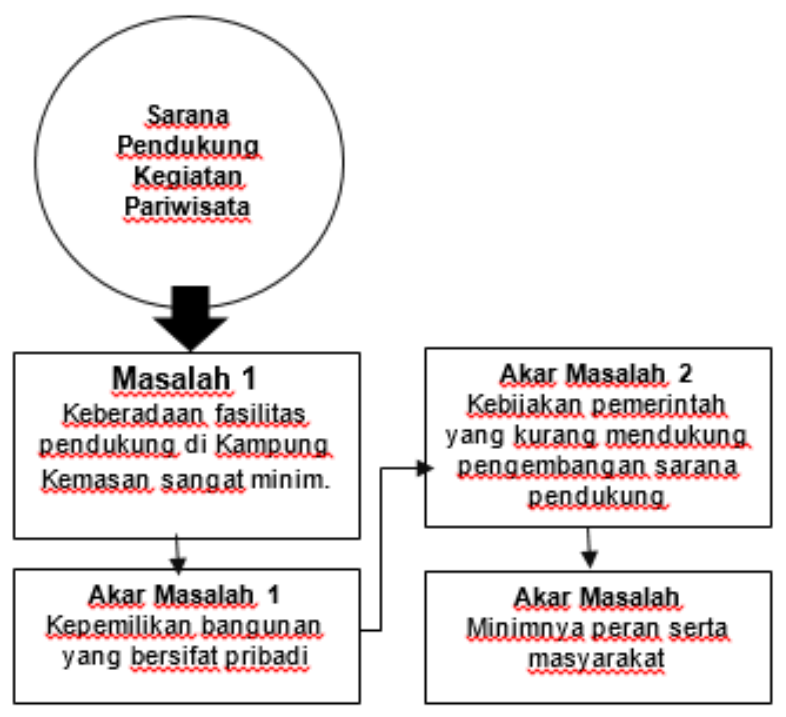

- Sarana dan prasarana pendukung Kegiatan Pariwisata

Keberadaan fasilitas pendukung wisata di Kampung Kemasan sangat minim. Hal ini disebabkan karena minimnya

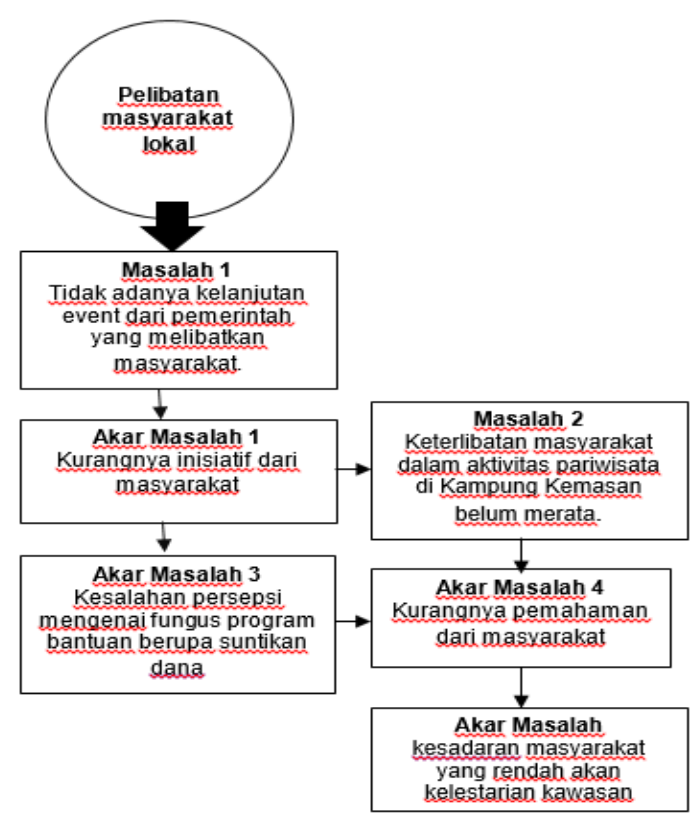

kebijakan dari pemerintah dalam mengadakan fasilitas yang dapat terlaksana. Kondisi ini disebabkan karena keterbatasan akses pemerintah terhadap sebagian besar kawasan yang besifat privat. Disisi lain, peran masyarakat terkait penyediaan fasilitas terlihat masih sangat minim.

Dari kondisi aksesibilitas, kondisi akses jalan menuju kampung kemasan yang memutar-mutar sehingga cenderung membingungkan wisatawan yang akan berkunjung. Kondisi akses jalan yang memutar ini dikarenakan belum adanya konsep manajemen wisata yang baik. 


\section{- Pengaruh Peningkatan}

Kesejahteraan Masyarakat Lokal

Pemanfaatan Dana/Program Pemerintah dalam Pengembangan Masyarakat Lokal

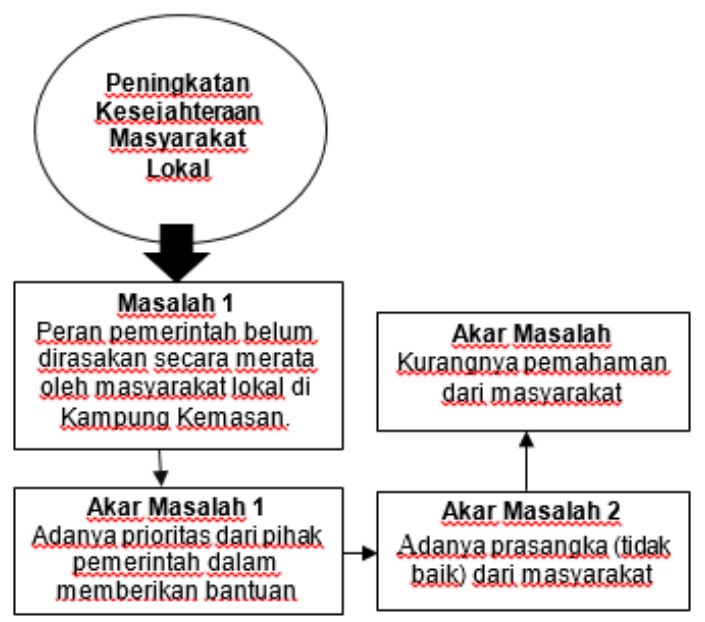

peran pemerintah belum dirasakan secara merata oleh masyarakat lokal di Kampung Kemasan. Hal ini disebabkan oleh adanya prioritas dari pihak pemerintah dalam memberikan bantuan. Prioritas yang dimaksud adalah mengenai bantuan yang diberikan terlebih dahulu pada bangunan rumah yang sudah ditetapkan menjadi bangunan cagar budaya. Prioritas ini ditentukan berdasarka hasil musyawarah dengan pelibatan masyarakat sekitar.

Konflik terjadi diantara masyarakat sendiri akibat adanya prasangka atau kekhawatiran tertentu pada proses pemilihan prioritas bangunan yang mendapat bantuan. Akhirnya adanya bantuan ini menimbulkan kesenjangan social.

\section{Pelibatan Masyarakat Lokal}

Keterlibatan Masyarakat Lokal dalam Pengembangan Kawasan Wisata

Tidak adanya kelanjutan event dari pemerintah yang melibatkan masyarakat disebabkan kurang antusiasnya inisiatif masyarakat dalam pengembangan kampung (event Djaloe). Gerakan massa yang tidak terlalu massive dikarenakan pemahaman yang berbeda pada masing masing anggota kampung dimana ada anggapan bahwa tanggung jawab mengenai kelestarian kampung ada ditangan pemerintah dan bantuan uang dari pemerintah merupakan insentif (karena berhasil mempertahankan bangunan cagar budaya). Sebenarnya, program bantuan uang dari pemerintah diberikan pada komunitas masyarakat untuk mengorganisir keterlibatan masyarakat baik dalam pengadaan event maupun maintenance kampung. Tidak sinkronnya tujuan program antara pemerintah dan masyarakat dikarenakan kurangnya pemahaman dan adanya sosialisasi yang berbeda penyampaian dari pihak atas ke pihak bawah. Disisi lain, keterlibatan masyarakat terhadap pengembangan aktivitas wisata disebabkan oleh adanya kekhawatiran dampak jika wisata berkembang. Masyarakat kampung belum 


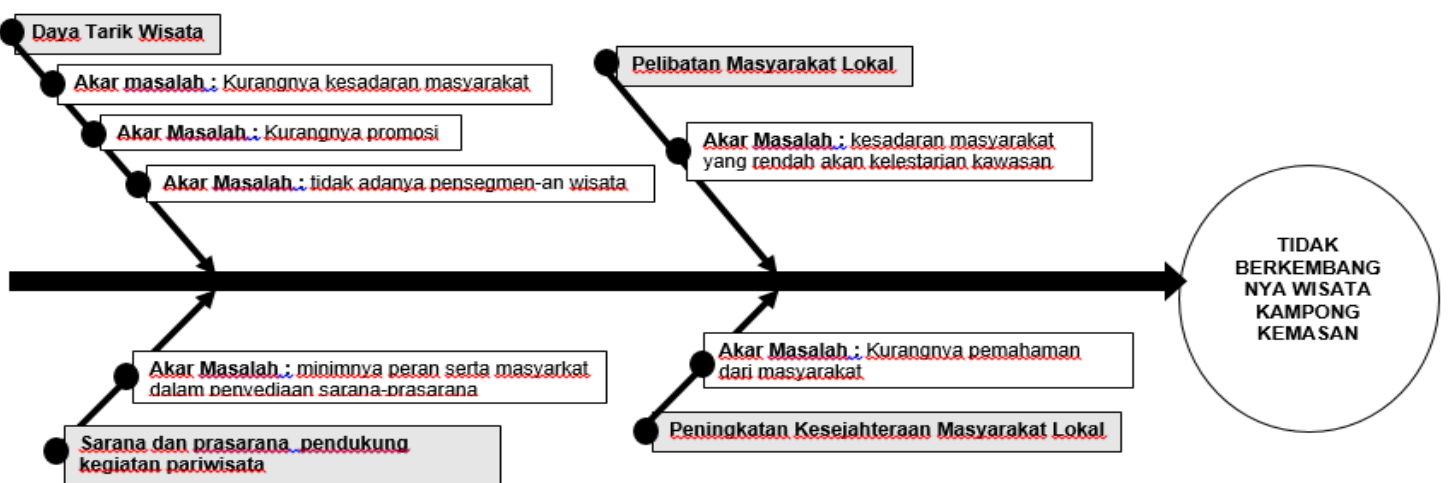

siap untuk menerima perumbahan yang cenderung lebih mengarah ke dinamis akan merubah way of life masyarakat kampung.

Dari keseluruhan gambaran kondisi kampong kemasan, beberapa indikator dan variabel yang berpengaruh terhadap pengembangan kawasan wisata cagar budaya memiliki akar permasalahan yang menjadi penyebab lambatnya perkembangan yang terjadi. Jika digambarkan dalam sebuah alur, akar permasalahan yang dapat ditarik adalah :

Berdasarkan hasil analisa RCA disimpulkan bahwa akar permasalahan tidak berkembangnya wisata cagar budaya kampong kemasan adalaha dikarenakan kesadaran masyarakat yang rendah akan kelestarian kawasan dikarenakan kurangnya pemahaman terhadap program program pengembangan yang ditetapkan pemerintah. Kurangnya pemahaman dan rendahnya kesadaran masyarakat menyebabkan minimnya peran serta masyarakat terutama dalam pengadaan sarana-prasarana pendukung wisata akhirnya daya Tarik wisata tidak berkembang dengan baik karena tidak adanya manajemen dan kurangnya promosi.

Hasil penerapan metode RCA terhadap studi kasus pengembangan kawasan wisata cagar budaya Kampung
Kemasan diketahui akar permasalahan dari tidak berkembangnya kawasan wisata. Pemahaman ini didapatkan dari hasil analisa komprehensif melibatkan stakeholder expert yang dianggap paham untuk merepresentasikan kondisi wisata Kampung Kemasan. Stakeholder yang ditetapkan adalah : (i) Disbudpora Kab. Gresik, (ii) Duta wisata Kab Gresik 2015/2016, (iii) Masyarakat pemilik bangunan di kampung, dan (iv) Ketua komunitas masyarakat.

Berdasarkan beberapa prinsip metoda analisa yang digunakan dalam proses perencanaan, posisi RCA memiliki :

Tabel 3. Prinsip RCA dibandingkan dengan metoda yang digunakan dalam perencanaan

\begin{tabular}{|l|c|c|}
\hline \multicolumn{1}{|c|}{ Prinsip pemahaman } & $\checkmark$ & Tidak \\
\hline $\begin{array}{l}\text { Idenifikasi } \\
\text { terhadap studi kasus }\end{array}$ & $\checkmark$ & \\
\hline $\begin{array}{l}\text { Hasil analisa merupakan } \\
\text { produk pertimbangan dalam } \\
\text { perumusan strategi } \\
\text { penanganan masalah sebagai }\end{array}$ & $\checkmark$ & \\
\hline $\begin{array}{l}\text { Melibatkan expert sebanamber } \\
\text { narasumber }\end{array}$ & & \\
\hline
\end{tabular}

Dari prinsipnya, metoda RCA memiliki karakteristik prinsip yang sama dibandingkan dengan metoda lain yang sering digunakan dalam proses perencanaan (AHP, DELPHI, SWOT, Content analysis).

\section{KESIMPULAN}

Penerapan metoda RCA terhadap studi kasus disimpulkan cukup efektif digunakan dalam memahami akar permasalahan karena sifatnya yang komprehensif dan mendalam (guna 
memahami peristiwa). Perbandingan prinsip dengan metode lain, didapatkan hasil bahwa metode RCA memiliki prinsip yang sama dengan metode lain yang biasa digunakan dalam perumusan produk perencanaan, namun mengerucut pada alasan mendalam terhadap sebuah atau beberapa permasalahan. Temuan dari hasil diagramatis RCA membantu menstrukturkan secara efektif dalam memahami sebuah peristiwa dan dapat digunakan sebagai pertimbangan dan pedoman perumusan strategi dalam produk perencanaan maupun penelitian khususnya dalam lingkup kawasan wisata cagar budaya.

\section{REFERENCES}

[1] Rooney, James J. and Houvol, Leo N Vandon. (2004). Root Cause Analysis For Beginners. www.asq.org

[2] Widodo, Sugeng. (2000). Studi Pelestarian Kompleks Masjid Menara Kudus dan Kawasannya. Suaka Peninggalan Sejarah dan Purbakala Propinsi Jawa Tengah.

[3] Travel.kompas.com. Jalan-jalan ke Kampung Kemasan, Yuk!. Diakses pada tanggal 3 juli 2016

[4] Supriharjo, Rimadewi, dkk. (2015). Pelestarian Kawasan Cagar Budaya Kampung Kemasan Kabupaten Gresik Dengan Pendekatan Partisipasi
Masyarakat. Surabaya : LPPM ITS.

[5] Kountur, R. (2005). Metode Penelitian Untuk Penulisan Skripsi dan Tesis. Jakarta : Penerbit PPM.

[6] Gretzky, Wayne. (2010). Strategic Planning and SWOT Analysis. Essentials of Strategic Planning in Healthcare

[7] Shannon, Sarah E. (2005). Three Approaches to Qualitative Content Analysis. Qualitative Health Research, Vol. 15 No. 9, November 2005 1277-1288

[8] Saaty. Thomas L. (2008). Decision making with the analytic hierarchy process. Katz Graduate School of Business, University of Pittsburgh, Pittsburgh, PA 15260, USA

[9] Chien Hzu, Chia. (2007). The Delphi Technique: Making Sense Of Consensus.The Ohio State University \& Brian A. Sandford, Oklahoma State University. ISSN 1531-7714

[10] Wibisono, Alga T. (2016). Laporan Tugas Akhir: Pengembangan Kawasan Wisata dengan Pendekatan Community-based Tourism di Kampung Kemasan, Gresik. PWK ITS. 